\title{
REVIEW
}

\section{Planning Large-scale Feed Production for Japanese Cattle Farming under the Condition of Cropland Dispersion}

\author{
Tetsufumi KUBOTA* \\ Division of Lowland Farming Research, Hokkaido Agricultural Research Center, National \\ Agriculture and Food Research Organization (Sapporo, Hokkaido 062-8555, Japan)
}

\begin{abstract}
With increases in the scale of feed-crop production in farm management, croplands are dispersed into larger areas and feed-crop production become more expensive. Here I examine how to increase feed production economically through livestock farm management under the condition of cropland dispersion. I constructed farming models reflecting cropland dispersion based on farm surveys and simulated optimized feed production by using the integer programming method. In the first study, I analyzed the effect of dispersion of feed-cropping fields on the management entities of breeding cattle for beef in the Kyushu District of Japan. The simulation results suggested that large-scale beef calf-raising farms would need to use feed-cropping fields $\leqq 1 \mathrm{~km}$ from the cattle sheds to achieve increased feed self-sufficiency. Moreover, if a farm has a total of 14 ha of fields at 0.4 ha per field $\leqq 3 \mathrm{~km}$ from the cattle shed, it would cover expenses even if calf prices declined to the support price. My second study revealed that feed crop-production costs could be decreased by optimizing feedcrop allocation (grasses and corn) to the fields around the total mixed ration (TMR) center run by Hokkaido dairy farmers. This could be achieved depending on the state of activities of the center that contracts out the harvesting and bunkering operations and on harvesting conditions.
\end{abstract}

Discipline: Farm economics

Additional key words: farming model simulation, integer programming method, distance from sheds to feed-cropping fields, feed-crop allocation to the fields, TMR center

\section{Introduction}

After World War II, there was remarkable development of farm management entities raising commercial livestock in Japan, and this improved the Japanese diet. The development of these entities, however, has relied on imported feed (Japan Livestock Industry Association, 1999). For this reason, Japanese stockbreeding suffered heavy damage from the surge in the price of imported feed in autumn 2008 (Ministry of Agriculture, Forestry and Fisheries 2015b), leading to a realization that feed self-sufficiency is important in Japan.

Researchers in the field of agricultural economics state that feed self-sufficiency is important because of the need for food self-sufficiency, food security, environmental protection, feed-safety, and the effective use of land (Syogenji 2000). Despite these needs, it is not yet clear how feed production in Japan can be increased economically. Especially, it is unclear how large-scale feed-crop production can be planned under the condition of cropland dispersion. Here, therefore, I attempted to determine the measures that could be used to increase feed production.

In the first study, I analyzed the effect of cropland dispersion coinciding with the expansion of domestic feed production on the cost of feed to farm management entities breeding beef cattle in the Kyushu district (Kubota 2012). In the second study, my research group examined the optimized allocation of feed crops, such as grass and corn, to the fields belonging to a total mixed ration (TMR) center run by dairy farmers, which produces and delivers TMR to dairy farms in Hokkaido (Kubota \& Fujita 2011). In these two studies, I have conducted farm surveys, constructed farming models based on the surveys, and simulated optimized farming state by using the integer programming method.

\footnotetext{
*Corresponding author: e-mail bota@affrc.go.jp

Received 30 March 2018; accepted 5 October 2018.
} 


\section{Effect of land dispersion on cost of feed production (Kubota 2012)}

\section{Objective of analysis}

As production lands become dispersed over a large area, feed production becomes more costly because the distance from cattle sheds to the croplands becomes long. This is likely to weaken the cost advantage of local feed production over imported feed. Accordingly, the maximum cattle-shed-to-field-distance that retained an advantage in feed-production costs over imported feed needs to be calculated. First, I investigated large-scale beef cattle breeding farms to gather information on feedproduction costs and the state of field dispersion. Second, I constructed a farming model based on the survey results and then simulated optimum farming state aiming at a maximum farming income.

\section{Survey results}

I investigated five managed farms in Kagoshima Prefecture and three in Nagasaki Prefecture. Kagoshima Prefecture contained vast upland farming areas, whereas the farms in Nagasaki Prefecture were hilly or mountainous. All the farms investigated had $>100$ breeding beef cattle and produced feed over areas with a range of 7-10 ha.

The average distance from the cattle sheds to the feed-cropping field on each farm was 1-4 km, except for one farm which has a field $40 \mathrm{~km}$ away. The average greatest distance to a field on each farm was $6 \mathrm{~km}$. One farm had feed-cropping fields $<1 \mathrm{~km}$ away from the sheds. Feed-cropping fields on the farms in Kagoshima Prefecture had an average area of 0.4 ha; the number of fields per farm was 15-41, and the fields were grouped in three to six blocks, each of which has three to eight fields. The feed-cropping fields on the farms in Nagasaki Prefecture had an average area of 0.2 ha; the number of fields per farm was 48-64, and the fields were grouped in three to seven blocks, each of which has eight to 21 fields.

\section{Farming model}

My farming model was that of a beef cattle breeding farm. It is aimed to maximize farming income by calf selling for fattening cattle with feed production and feed purchase. The model has four family workers, one cattle shed which accommodates 150 heads of cattle, and one block of fields around the shed and three or four or five distant blocks of fields.

Figure 1 shows a pattern diagram of the farming model constructed by the integer programming method. The figure indicates that the model consists of fixed cost processes, feeding cattle process, feed-crop production processes, feed supply processes to cattle, including the purchasing feeds and feed nutrition adjustment processes to proper proportion. The model has 220 processes and 305 constraints.

In the model, beef calf price is set up to 410,000 yen which is the average price of beef cattle in the Wagyu calf auction market from fiscal year of 1999 to 2008 in Japan.

Feed production processes represent grass harvest

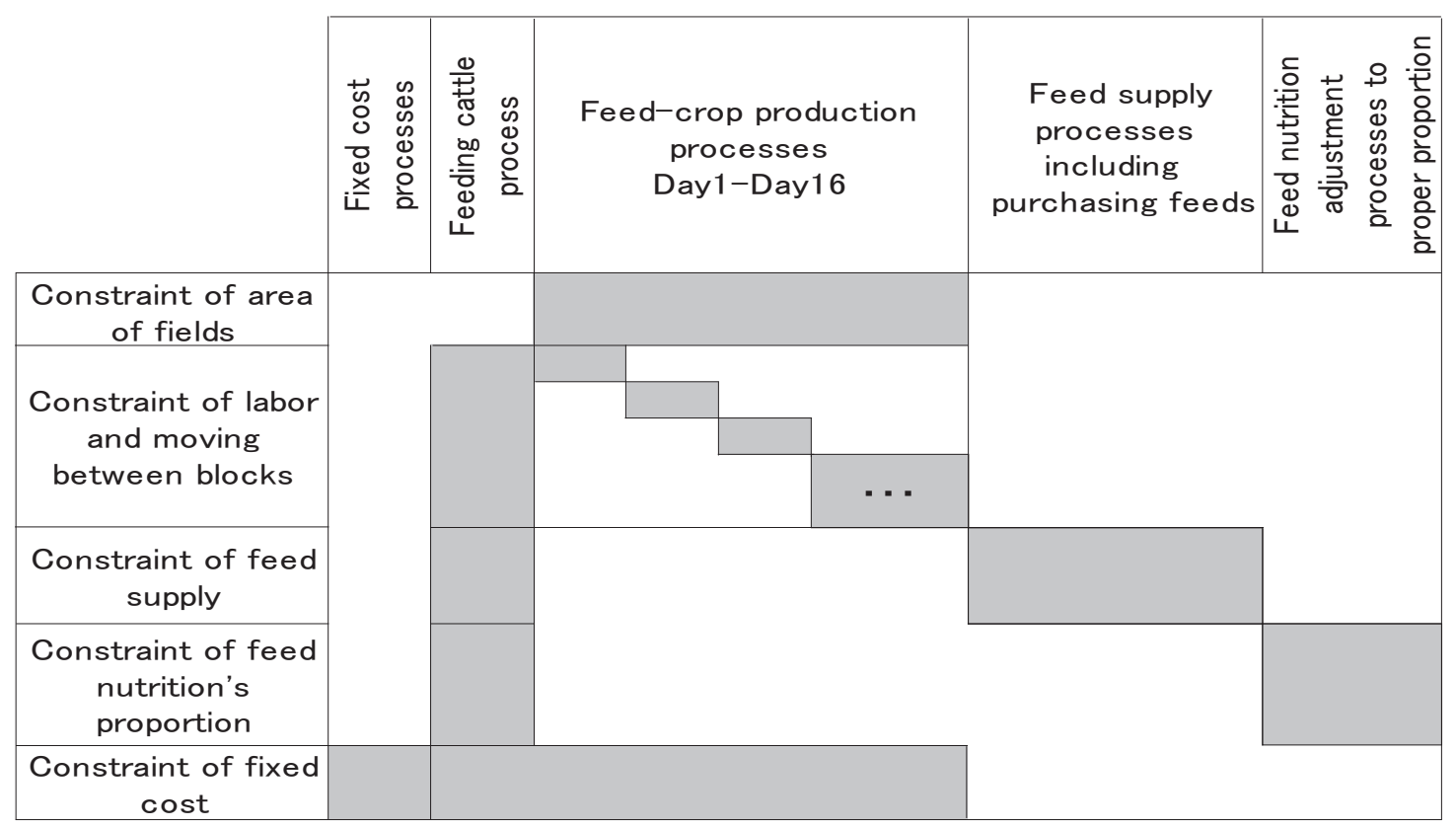

Fig. 1. Pattern diagram of farming model 1

Main technical coefficients are written in the gray parts. 
work in April because of the busiest farming season. Feed production processes naturally are given an annual cost of feed production. According to the weather data, there are sixteen days to conduct farming except for rainy days in April.

Feed-production process is set up as the integer process in every field. Working time to raise beef calves raising and feed production is limited to within 8 hours every day.

In producing feed crops, the model initially uses a block of fields around the shed. After finishing use of the block around the shed, the model begins to use block of fields that are farther way to produce feed crops. Usually, one block of fields is around the shed and the remaining three to five blocks are away from the shed. The field blocks were numbered as follows: one is the block around the shed; distant blocks are assigned numbers two, three, four, etc. In producing feed crops, model uses blocks in ascending order.

I then conducted a simulation of distance from sheds to fields. The total number of combinations in the simulation model was 540 . There were three different numbers for feed-cropping blocks per farm (four, five, and six); three different numbers for fields per block (four, six, and eight); two acreages of fields $(0.2$ and $0.4 \mathrm{ha})$; 10 different distances to each block (from $10 \mathrm{~km}$ to $1 \mathrm{~km}$ in steps of $1 \mathrm{~km}$ ); and three different distances between fields in the same block $(0,50$, and $100 \mathrm{~m})$.

\section{Round trip and one-way trip from the shed to blocks to conduct feed-crop production in the model}

Tables 1 and 2 show the simplex table of the component of feed production. When the model uses distant blocks to feed-crop production, roundtrip processes from the shed to distant block work simultaneously. For instance, in Tables 1 and 2, when the "Decision of last block number at the second day" process that is established in ninth file works for one, the "Not going to the distant block and back at the second day" process that is established in $10^{\text {th }}$ file which does not influence the result of simulation works by the constraint set up in the $13^{\text {th }}$ line because block one is not a distant block. The process established in $10^{\text {th }}$ file works before the $11^{\text {th }}$ process works because the $11^{\text {th }}$ process has a minus coefficient of profit. The $10^{\text {th }}$ process works for only one because of the limit by $14^{\text {th }}$ line's constraint. Therefore, when the ninth file's process works over two, the $11^{\text {th }}$ file's process works for one, which influences the result of simulation on a cost and work time of round trip from shed to field.

When the farming model uses more than two distant blocks, one-way processes also work. By round-trip and one-way process, the farming model can reflect the effects of land dispersion in terms of cost and working time for feed-crop production. For example, when ninth file's process works for two, in other words, farming model finishes working for feed-crop production at block two at the second day, and process of $13^{\text {th }}$ file, "Decision of starting block number at the second day," works for one, that is, when the farming model starts working for feedcrop production at block one, or the block around the shed, the $14^{\text {th }}$ file's process, "Moving for another block of field at the second day," works for one according to $19^{\text {th }}$ line's constraint. However, moving from block one to block two is not one-way trip but is a round-trip, because one-way is moving process between distant blocks, and round-trip process already has been reflected into simulation by $11^{\text {th }}$ file's process. Then, a process, "Denial of moving at the second day," set up in $15^{\text {th }}$ file, works for one by $20^{\text {th }}$ line's constraint, which contradicts the influence of one-way moving process set up in $14^{\text {th }}$ file.

In addition, when ninth file's process works for three, in other words, farming model finishes working for feed-crop production at block three, and $13^{\text {th }}$ file's process works for one, $14^{\text {th }}$ file's process works for two. In this case, as mentioned above, moving from block one to block two is not a one-way process but a round-trip, and moving from block two to block three is just a one-way process. After all, $14^{\text {th }}$ file's process works extra. Accordingly, $15^{\text {th }}$ file's process works for one by $20^{\text {th }}$ line's constraint, contradicting one of the influences of one-way moving process that is set up in $14^{\text {th }}$ file, similar to the above.

In the case where $13^{\text {th }}$ file's and ninth file's processes work for one each or in the case of both zero, because feed-crop production has not been done, moving between distant blocks process is contradicted by $14^{\text {th }}, 15^{\text {th }}$ and $16^{\text {th }}$ file's process.

\section{Simulation results}

When each field covers an acreage of 0.4 ha, feedcrop production is conducted within 6.4-12.8 ha in the case of distances of $1 \mathrm{~km}$ from sheds to field. In the case of distances of $2 \mathrm{~km}$, feed-crop production is also conducted within 7.2-8.0 ha, except for the case of four blocks and four fields per block. In the case of distances of $3 \mathrm{~km}$, feed-crop production is conducted within 8.0 ha only in the case of eight fields per block and adjacent fields in the same block (Table.3).

If the case of an increase in the price of calves from 410,000 to 530,000 yen, no farming model allowed the farms to produce feed crop. By contrast, with a fall in the price of calves to 310,000 yen-the security price set by Japanese government for farms-all the farming models 
Table 1. Simplex table for simulation of economically advantageous distance to field on livestock farm (1) (an extract)

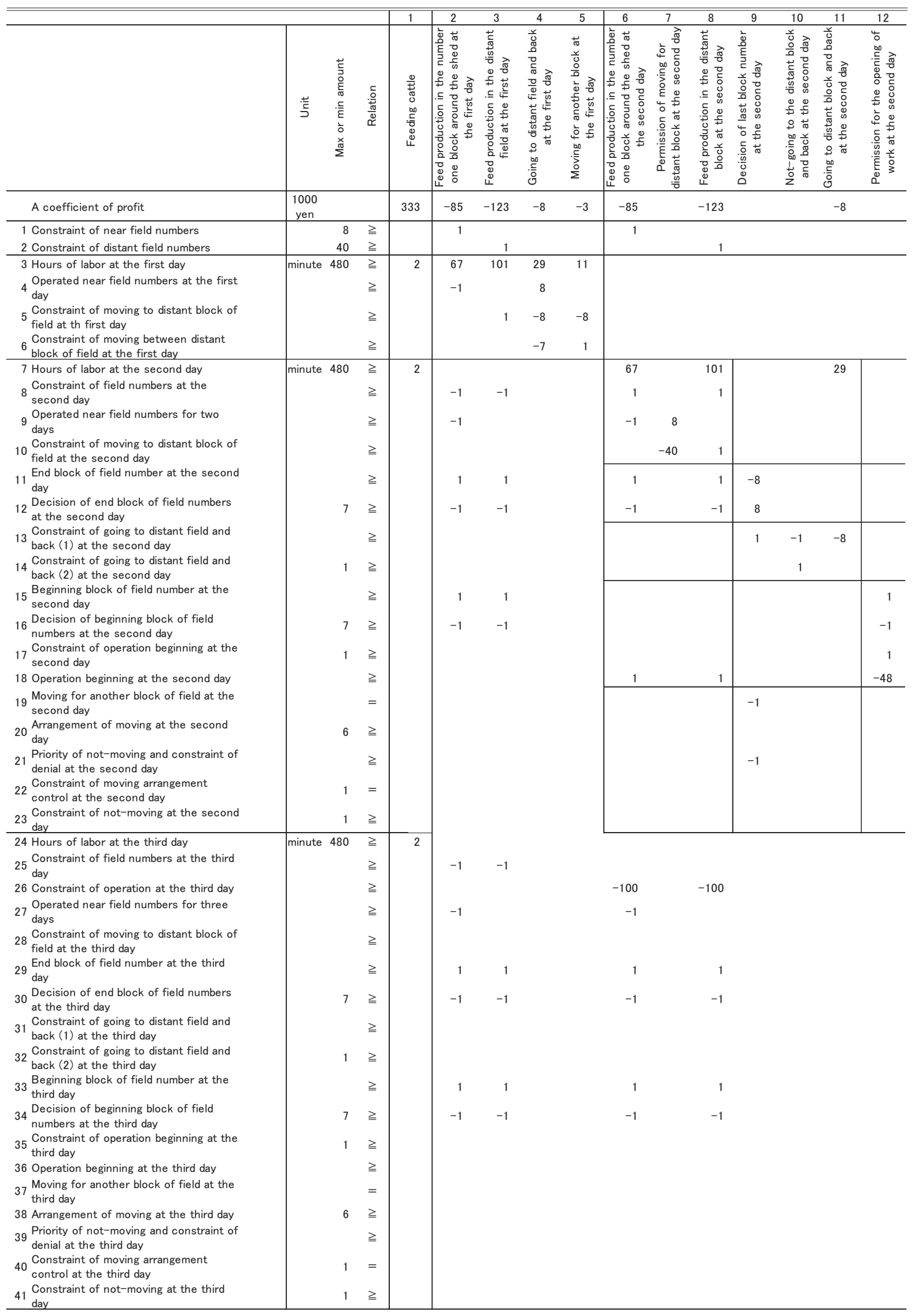

This simplex table shows the case of 0.4 hectare per field. 
Table 2. Simplex table for simulation of economically advantageous distance to field on livestock farm (2) (an extract)

\begin{tabular}{|c|c|c|c|c|c|c|c|c|c|c|c|c|c|c|c|c|c|c|}
\hline 13 & 14 & 15 & 16 & 17 & 18 & 19 & 20 & 21 & 22 & 23 & 24 & 25 & 26 & 27 & 28 & 29 & 30 & 31 \\
\hline 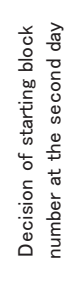 & 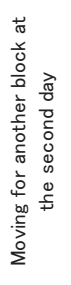 & 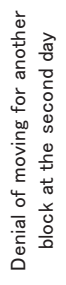 & 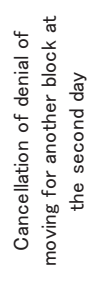 & 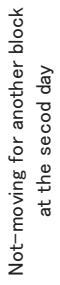 & 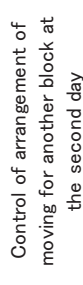 & 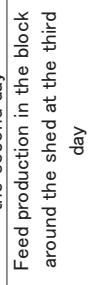 & 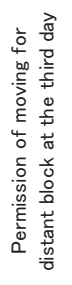 & 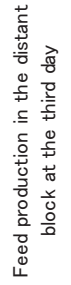 & 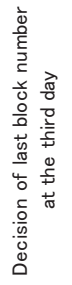 & 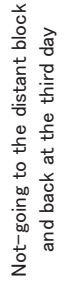 & 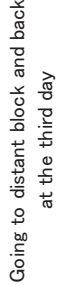 & 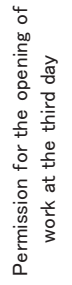 & 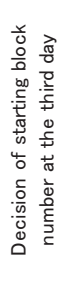 & 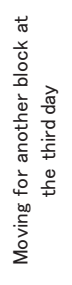 & 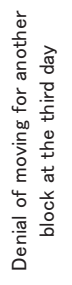 & 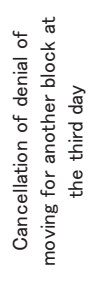 & 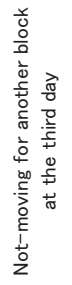 & 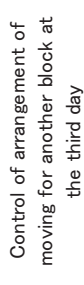 \\
\hline & \multirow[t]{2}{*}{-3} & 3 & -3 & & & -85 & & -123 & & & -8 & & & -3 & 3 & -3 & & \\
\hline & & & & & & 1 & & 1 & & & & & & & & & & \\
\hline
\end{tabular}

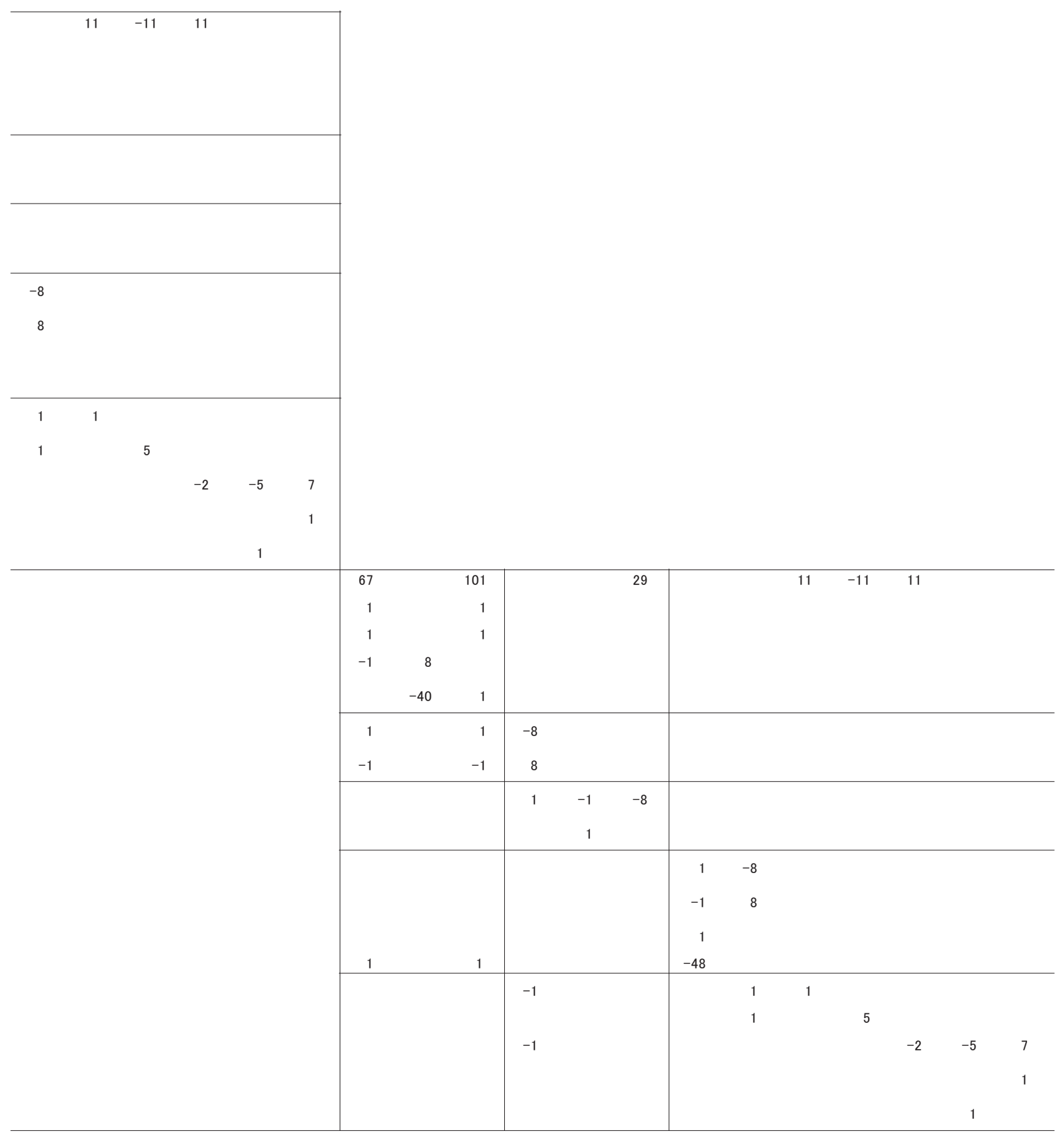


enable feed-crop production.

With a fall in the price of calves to 310,000 yen, distance of $3 \mathrm{~km}$ to the fields gave a farm income of $4,370,000$ yen under the best conditions of field dispersion, namely a field area of 0.4 ha, six blocks, with eight fields per block and adjacent fields in the same block. In 2008, beef calf-raising farms in the Kyusyu District were each estimated to need 4,050,000 yen to cover their expenses. Therefore, if the distance from the cattle sheds to feedcropping fields was within $3 \mathrm{~km}$, beef calf-raising farms could get by on a farming income even if the price of calves were to fall to 310,000 yen. Under this scenario, a farm would have 104 heads of breeding cattle, 14.4 ha of feed-production fields, and $92.4 \%$ feed self-sufficiency.

\section{Conclusion}

The simulation results suggest that large-scale beef calf-raising farms need to have their feed-cropping fields within the distance of $1 \mathrm{~km}$ from the cattle sheds to increase the rate of feed self-sufficiency. Moreover, it is important for farms to produce feed crop to secure the farm against fall in calf price, even if it is impossible to have fields within $1 \mathrm{~km}$ of the cattle shed. If a farm has a total of 14 ha of fields at 0.4 ha per field, within $3 \mathrm{~km}$ of the cattle shed, it would be able to cover expenses, even if the price of calves were to decline heavily.

\section{Optimized allocation of feed-crop production around a TMR center (Kubota \& Fujita 2011)}

\section{Objective of analysis}

The feed-cropping fields of a TMR center are likely to be dispersed over an area larger than that of the fields for farming. However, just as on farms, harvested feed crops are collected at one storage point of the TMR center. Therefore, distance from the storage site at the TMR center to the feed-cropping fields can become very great, leading to a high cost of feed production.

I showed here that, when feed crops such as grasses and corn are arranged appropriately according to distance to fields and working systems, the cost of feed-crop production could be decreased. First, I conducted a survey of the TMR center to gather data on distance to fields and cost of feed-crop production. Second, I constructed a farming model and used the model to simulate the allocation of feed crops to minimize the cost of feed production.

\section{Survey results}

The TMR center surveyed by us is run by six dairy farms with 440 heads of milking cows. It has 300 ha of feed-cropping fields, and it uses 200 ha of those fields for grass production and 100 ha for corn. In terms of the distance from the TMR center to the fields, 100 ha was 1 $\mathrm{km}$ away, 75 ha was $1-3 \mathrm{~km}$ away, 90 ha was $3-5 \mathrm{~km}$ away, and 35 ha was 5-7 km away.

The TMR center contracts a local construction firm to operate the harvesting machinery, transport the harvested feed crops in about three to five dump trucks (each with a carrying capacity of $10 \mathrm{t}$ ), and pack the feed crops into a bunker silo.

\section{Farming model}

The farming model represents the TMR center producing feed crops. Figure 2 shows a pattern diagram of whole farming model and Tables 4 and 5 show an extracted simplex table constructed by an integer programming

Table 3. Acreage of feed production by simulation

\begin{tabular}{|c|c|c|c|c|c|c|c|c|c|c|c|}
\hline \multirow{3}{*}{$\begin{array}{l}0 \\
00 \\
0 \\
0 \\
\frac{1}{0} \\
0 \\
\frac{0}{0} \\
\frac{0}{1}\end{array}$} & \multirow{3}{*}{ 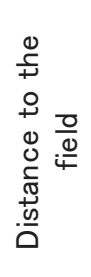 } & \multirow{3}{*}{ 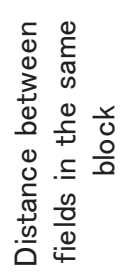 } & \multicolumn{9}{|c|}{ Acreage } \\
\hline & & & \multicolumn{3}{|c|}{ Six blocks } & \multicolumn{3}{|c|}{ Five blocks } & \multicolumn{3}{|c|}{ Four blocks } \\
\hline & & & $\begin{array}{l}\text { Eight } \\
\text { fields } \\
\text { (ha) }\end{array}$ & $\begin{array}{c}\text { Six } \\
\text { fields } \\
\text { (ha) }\end{array}$ & $\begin{array}{l}\text { Four } \\
\text { fields } \\
\text { (ha) }\end{array}$ & $\begin{array}{l}\text { Eight } \\
\text { fields } \\
\text { (ha) }\end{array}$ & $\begin{array}{c}\text { Six } \\
\text { fields } \\
\text { (ha) }\end{array}$ & $\begin{array}{l}\text { Four } \\
\text { fields } \\
\text { (ha) }\end{array}$ & $\begin{array}{l}\text { Eight } \\
\text { fields } \\
\text { (ha) }\end{array}$ & $\begin{array}{c}\text { Six } \\
\text { fields } \\
\text { (ha) }\end{array}$ & $\begin{array}{c}\text { Four } \\
\text { fields } \\
\text { (ha) }\end{array}$ \\
\hline \multirow{9}{*}{$0.4 \mathrm{ha}$} & & $0 \mathrm{~m}$ & 12.8 & 12.8 & 9.6 & 12.8 & 12.0 & 6.4 & 12.8 & 9.6 & 6.4 \\
\hline & $1 \mathrm{~km}$ & $50 \mathrm{~m}$ & 12.8 & 12.8 & 9.6 & 12.8 & 12.0 & 6.4 & 12.8 & 9.6 & 6.4 \\
\hline & & $100 \mathrm{~m}$ & 12.8 & 12.8 & 9.6 & 12.8 & 12.0 & 6.4 & 12.8 & 9.6 & 6.4 \\
\hline & & $0 \mathrm{~m}$ & 8.0 & 7.6 & 7.2 & 8.0 & 7.6 & 7.2 & 8.0 & 7.6 & - \\
\hline & $2 \mathrm{~km}$ & $50 \mathrm{~m}$ & 8.0 & 7.6 & 7.2 & 8.0 & 7.6 & 7.2 & 8.0 & 7.6 & - \\
\hline & & $100 \mathrm{~m}$ & 8.0 & 7.6 & 7.2 & 8.0 & 7.6 & 7.2 & 8.0 & 7.6 & - \\
\hline & & $0 m$ & 8.0 & - & - & 8.0 & - & - & 8.0 & - & - \\
\hline & $3 \mathrm{~km}$ & $50 \mathrm{~m}$ & - & - & - & - & - & - & - & - & - \\
\hline & & $100 \mathrm{~m}$ & - & - & - & - & - & - & - & - & - \\
\hline
\end{tabular}

The price of calf has been assumed to be equal to 410,000 yen. 
method. The farming model consists of processes such as feed-crop-harvesting processes arranged according to the distance of blocks, number of trucks, truck number selection processes, and operating cost processes. Table 6 shows the conditions and the limitations of simulation by the farming model that aimed to minimize the cost of harvesting feed crops by allocating feed crops to each field under the necessary field area conditions and limitations on the operating conditions.

\section{Simulation results}

The results of simulations are provided in Table 7. Under the first set of conditions, corn is allocated into fields located 1,3 , and $5 \mathrm{~km}$ from the storage site at the TMR center. In fact, because the corn-producing fields at the TMR center are located at the same distances from the center, the model simulations reproduced the allocation of corn well.

When the maximum number of trucks is increased to five, corn was allocated to fields that are farther away than the first set conditions and grasses were allocated to nearby fields. Next, under conditions in which the cropping terms of corn harvest are shortened from 7 to 6 days, the modeled locations of some of the corn are changed to fields $3 \mathrm{~km}$ away so that the corn-harvesting operations would end within 6 days.

If the TMR center does not contract out the harvesting and bunkering operation to the local construction firm, the hourly cost of harvesting the crops falls. Thus, costs could be decreased even when the number of trucks is decreased and if the harvesting time is extended. Under this scenario, the feed-crop allocations are again changed. Corn is allocated to nearby fields ( 3 and $5 \mathrm{~km}$ from the center) because it is necessary to finish harvesting corn within 6 days with a lower number of trucks.

\section{Conclusion}

As mentioned above, depending on whether the TMR center contracted out the harvesting and bunkering operations and on harvesting conditions, the center could decrease the cost of feed-crop production by arranging the allocations of feed crops and changing the number of dump trucks. The analysis covered a comparatively small-scale TMR center. With a large-scale center the cost of harvesting feed crops would likely fall further with such adjustments. It is thus important for TMR centers to consider the allocation of feed crops when planning their feed-crop production.

\section{Future studies}

These two studies have revealed how to use the dispersing feed-cropping fields to enable farms to produce feed crops efficiently. As domestic feed production has developed in Japan, livestock management seems to avoid heavy economic damage from a surge in imported feed prices. However, feed-crop harvest can be poor. Some TMR centers that produce TMR cheaply use the residues from the production of juice or tofu. Another future need is to determine the conditions under which these residues can be used with maximum efficiency by the TMR center.

According to Japan's Ministry of Agriculture,

\begin{tabular}{|l|c|c|c|}
\hline \multicolumn{1}{c|}{$\begin{array}{c}\text { Feed-crop production processes } \\
\text { per feed crop, } \\
\text { distance to blocks, } \\
\text { a number of trucks }\end{array}$} & $\begin{array}{c}\text { Cost } \\
\text { number of trucks per } \\
\text { feed crop }\end{array}$ & $\begin{array}{c}\text { Srocesses } \\
\text { per feed } \\
\text { crop area of fields }\end{array}$ \\
\hline $\begin{array}{c}\text { Constraint of } \\
\text { selection of a number } \\
\text { of trucks per feed crop }\end{array}$ & & & \\
\hline $\begin{array}{c}\text { Constraint of cost per } \\
\text { feed crop }\end{array}$ & & \\
\hline
\end{tabular}

Fig. 2. Pattern diagram of farming model 2

Main technical coefficients are written in the gray parts. 
Table 4. Simplex table for simulation of the allocation of feed crops based on cost (1) (an extract)

\begin{tabular}{|c|c|c|c|c|c|c|c|c|c|c|c|c|c|c|c|c|}
\hline & & & & & 1 & 2 & 3 & 4 & 5 & 6 & 7 & 8 & 9 & 10 & 11 & 12 \\
\hline & & 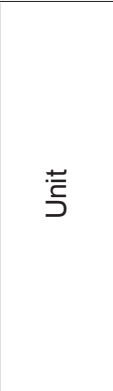 & 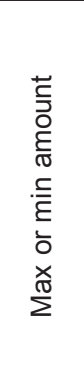 & 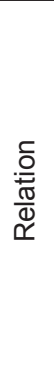 & 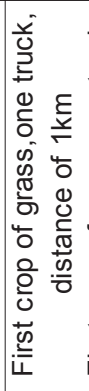 & 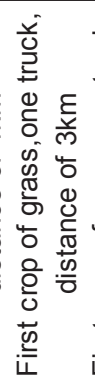 & 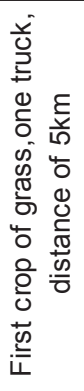 & 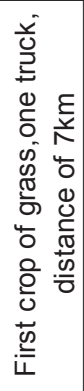 & 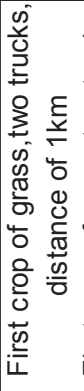 & 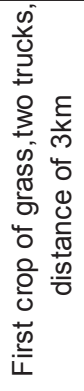 & 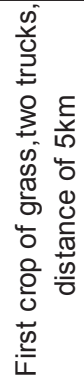 & 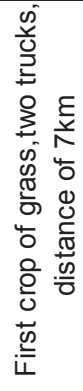 & 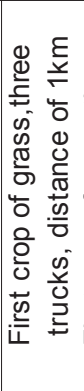 & 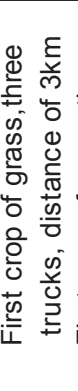 & 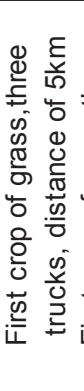 & 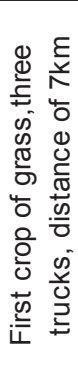 \\
\hline & A coefficient of cost & $\begin{array}{c}1000 \\
\text { yen }\end{array}$ & & & & & & & & & & & & & & \\
\hline & $\begin{array}{l}\text { Constraint of labor: } \\
\text { First crop of grass } \\
\text { Constraint of labor: } \\
\text { Second crop of grass } \\
\text { Constraint of labor: } \\
\text { Corn }\end{array}$ & minute & $\begin{array}{l}5040 \\
4200 \\
2880\end{array}$ & $\geqq$ & 221 & 393 & 566 & 738 & 113 & 198 & 284 & 369 & 94 & 136 & 194 & 251 \\
\hline 4 & $\begin{array}{l}\text { Constraint of acre: } \\
\text { Grass } \\
\text { Constraint of acre: } \\
\text { Corn }\end{array}$ & ha & $\begin{array}{l}200 \\
100\end{array}$ & $\leqq$ & 5 & 5 & 5 & 5 & 5 & 5 & 5 & 5 & 5 & 5 & 5 & 5 \\
\hline 9 & $\begin{array}{l}\text { Constraint of acre: } \\
\text { Distant block of fields: } \\
1 \mathrm{~km} \\
\text { Constraint of acre: } \\
\text { Distant block of fields: } \\
3 \mathrm{~km} \\
\text { Constraint of acre: } \\
\text { Distant block of fields: } \\
5 \mathrm{~km} \\
\text { Constraint of acre: } \\
\text { Distant block of fields: } \\
7 \mathrm{~km}\end{array}$ & ha & $\begin{array}{l}100 \\
75 \\
90\end{array}$ & $\geqq$ & 5 & 5 & 5 & 5 & 5 & 5 & 5 & 5 & 5 & 5 & 5 & 5 \\
\hline 15 & $\begin{array}{l}\text { Constraint of acre: } \\
\text { One truck } \\
\text { Constraint of acre: } \\
\text { Two trucks } \\
\text { Constraint of acre: } \\
\text { Three trucks } \\
\text { Constraint of acre: } \\
\text { Four trucks } \\
\text { Constraint of acre: } \\
\text { Five trucks } \\
\text { Selection of a number } \\
\text { of trucks }\end{array}$ & & 1 & $\geqq$ & 5 & 5 & 5 & 5 & 5 & 5 & 5 & 5 & 5 & 5 & 5 & 5 \\
\hline 18 & $\begin{array}{l}\text { Cost of the case: } \\
\text { One truck } \\
\text { Cost of the case: } \\
\text { Two trucks } \\
\text { Cost of the case: } \\
\text { Three trucks } \\
\text { Cost of the case: } \\
\text { Four trucks } \\
\text { Cost of the case: } \\
\text { Five trucks }\end{array}$ & & & $\geqq$ & 221 & 393 & 566 & 738 & 113 & 198 & 284 & - 369 & 94 & 136 & 194 & 251 \\
\hline
\end{tabular}


Table 5. Simplex table for simulation of the allocation of feed crops based on cost (2) (an extract)

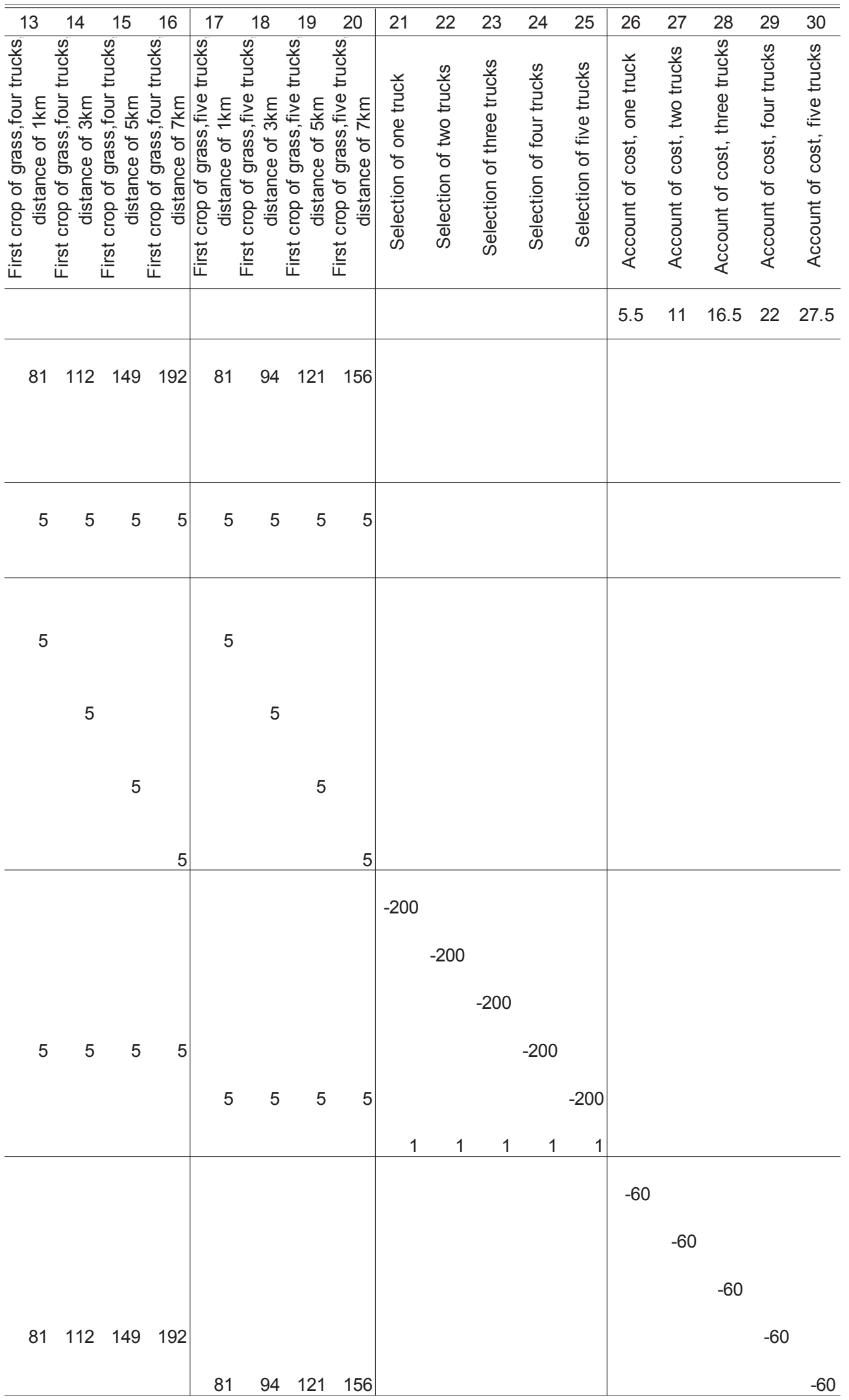


Table 6. Conditions of simulation

\begin{tabular}{ccccc}
\hline \hline Conditions & Number of trucks & $\begin{array}{c}\text { Cropping terms } \\
\text { of corn: Days }\end{array}$ & $\begin{array}{c}\text { Outsourcing of } \\
\text { crop harvesting }\end{array}$ & $\begin{array}{c}\text { Outsourcing of } \\
\text { bunkering }\end{array}$ \\
\hline $\begin{array}{c}\text { First conditions based on } \\
\text { survey }\end{array}$ & $3-4$ & 7 & Outsourcing & Outsourcing \\
$\begin{array}{c}\text { Increase in the maximum } \\
\text { number of trucks }\end{array}$ & 5 & 7 & Outsourcing & Outsourcing \\
$\begin{array}{c}\text { Reduction of cropping } \\
\text { terms of corn }\end{array}$ & 5 & 6 & Outsourcing & Outsourcing \\
$\begin{array}{c}\text { Stop outsourcing } \\
\text { except for truck work }\end{array}$ & 5 & 6 & $\begin{array}{c}\text { Stop } \\
\text { outsourcing }\end{array}$ & $\begin{array}{c}\text { Stop } \\
\text { outsourcing }\end{array}$ \\
\hline
\end{tabular}

Table 7. Allocation of feed crops to fields by simulation

\begin{tabular}{|c|c|c|c|c|c|c|c|c|}
\hline & \multicolumn{2}{|c|}{$\begin{array}{c}1 \mathrm{~km} \text { block } \\
100 \mathrm{ha}\end{array}$} & \multicolumn{2}{|c|}{$\begin{array}{c}3 \mathrm{~km} \text { block } \\
75 \mathrm{ha}\end{array}$} & \multicolumn{2}{|c|}{$\begin{array}{c}5 \mathrm{~km} \text { block } \\
90 \mathrm{ha}\end{array}$} & \multicolumn{2}{|c|}{$\begin{array}{c}7 \mathrm{~km} \text { block } \\
35 \mathrm{ha}\end{array}$} \\
\hline & $\begin{array}{l}\text { grass } \\
\text { (ha) }\end{array}$ & $\begin{array}{l}\text { corn } \\
\text { (ha) }\end{array}$ & $\begin{array}{l}\text { grass } \\
\text { (ha) }\end{array}$ & $\begin{array}{l}\text { corn } \\
\text { (ha) }\end{array}$ & $\begin{array}{l}\text { grass } \\
\text { (ha) }\end{array}$ & $\begin{array}{l}\text { corn } \\
\text { (ha) }\end{array}$ & $\begin{array}{l}\text { grass } \\
\text { (ha) }\end{array}$ & $\begin{array}{l}\text { corn } \\
\text { (ha) }\end{array}$ \\
\hline First condition & 95 & 5 & 0 & 75 & 70 & 20 & 35 & 0 \\
\hline $\begin{array}{c}\text { Increase in the number of } \\
\text { trucks }\end{array}$ & 100 & 0 & 75 & 0 & 25 & 65 & 0 & 35 \\
\hline $\begin{array}{l}\text { Reduction of cropping } \\
\text { terms of corn }\end{array}$ & 100 & 0 & 25 & 50 & 75 & 15 & 0 & 35 \\
\hline $\begin{array}{l}\text { Stop outsourcing on } \\
\text { harvesting and bunkering }\end{array}$ & 100 & 0 & 15 & 60 & 50 & 40 & 35 & 0 \\
\hline
\end{tabular}

Acreage of each field is 5 hectares.

Forestry, and Fisheries, food related industries produce about 20 million tons of waste; about 15 million tons of this is reused, mostly as feed. The amount of food waste from Japanese households is estimated at about 11 million tons; only about 0.5 million tons of this is reused. Therefore, about 15 million tons of waste is burned or buried (The Ministry of Agriculture, Forestry and Fisheries 2015a). It is important to determine how this food waste can be reused as feed.

\section{Acknowledgment}

These studies introduced in this review were partially supported by Grant-in-Aid for Scientific Research by Japan's Ministry of Education, Culture, Sports, Science and Technology (MEXT). In addition, these studies have been deposited in Kyoto University Research Information Repository (KURENAI) as a doctoral dissertation, and all the simplex tables used in these studies were obtained from the repository. Besides, these studies have been published as part of a collection of books from Central Region Agricultural Research Center and Hokkaido
Agricultural Research Center, as well as a book by the Association of Agriculture and Forestry Statistics.

\section{References}

Japan Livestock Industry Association (1999) History of livestock administration -After World War II- (book). Tokyo. Japan Livestock Industry Association.

Kubota T. \& Fujita N. (2011) Field arrangement model of feed crops for consignment operation cost reduction on TMR center. Jpn. J. Farm Manag., 150, 43-48.

Kubota T. (2012) Feed production conditions for a large-size calf-raising farm: An analysis using linear-programming method taking into account feed production transportation costs. Jpn. J. Farm Manag., 152, 1-15.

Ministry of Agriculture, Forestry and Fisheries: Present conditions of reused food waste estimated in 2012 fiscal year.http://www.maff.go.jp/j/shokusan/recycle/syoku_loss/ pdf/hurorev2.pdf

Ministry of Agriculture, Forestry and Fisheries (2015). Present Affairs Around Feed (Report).

Syogenji S. (2000) Composition of domestic feed matters. Survey about conditions of feed production land on livestock farm. Tokyo. Agricultural Policy Research Committee, Inc. 